\title{
RESPONS TERHADAP KONSEPSI ALLAH DALAM TEOLOGI PROSES
}

\author{
Hermawan \\ Providence Anglican Church \\ JIn. Pluit Karang Ayu Blok B1, Jakarta Utara \\ hermawancherish@gmail.com
}

\begin{abstract}
Process theology has influenced the worldview of Christian theology. It has emphasis on the doctrine of God. Process theology is consistently applied based on dipolar nature, namely the changing and unchanging nature. These two natures have affected the view of God. Process theology is also included as natural theology, which is seeking for theodicy purpose. In this article, there are two types of response toward process theology, appreciation and counter position. The responses will be elaborated based on theological concept and biblical studies approaches.
\end{abstract}

Keywords: concept, god, responses, process theology.

ABSTRAK: Teologi Proses telah mempengaruhi pandangan dunia teologi Kristen. Penekanan teologi proses adalah pada doktrin Allah. Teologi proses secara konsisten diterapkan berdasarkan sifat dipolar, yaitu sifat yang berubah dan tidak berubah. Kedua sifat ini mempengaruhi pandangan tentang Allah. Teologi Proses juga termasuk sebagai teologi alam, yang sifatnya mencari tujuan teodisi. Dalam artikel ini, ada dua jenis respons, yaitu penghargaan dan posisi berlawanan. Semua tanggapan akan dijelaskan berdasarkan pendekatan konsep teologis dan studi biblika.

Kata Kunci: konsep, tuhan, respon, teologi proses.

\section{PENDAHULUAN}

Makalah ini dikhususkan untuk membahas mengenai Allah yang dirumuskan dalam teologi proses, yang dicetuskan oleh Alfred Whitehead. Teologi ini berasal dari ilmu filsafat yang berkembang ke dalam dunia teologi. Konsepsi tentang Allah merupakan sesuatu yang sangat penting dan krusial untuk diangkat karena miskonsepsi tentang Allah memiliki implikasi teologis dan pengenalan yang bertolak belakang dengan Allah-Alkitab. Dalam bagian ini penulis menyajikan konsepsi Allah dalam teologi proses dan respons terhadap konsepsi tersebut menurut Christian Worldview yang berlandaskan kebenaran Alkitab tentang Allah.

Mengapa respons tersebut di dalam Christian Worldview? Hal ini dikarenakan dalam perkembangan konsepsi Allah ini, telah dikaitkan dengan teologi Kristen yang di- intepretasikan ulang tidak dalam kerangka filsafat proses. Dengan kata lain, konsepsi Allah dalam teologi proses bukanlah sebuah produk teologi Kristen yang lahir dari filsafat proses. Sehingga konsepsi Allah dalam teologi proses jauh berbeda dengan konsepsi Allah yang lahir dari teologi Kristen. Tujuan yang ingin dicapai dalam makalah ini adalah sebuah langkah apologia Kristen dan juga berharap mampu mempertegas perbedaan konsepsi Allah dalam teologi proses dan teologi.

\section{METODE}

Secara spesifik, makalah ini akan mendeskripsikan konsepsi Allah berdasarkan perspektif teologi proses dan respons terhadap konsepsi tersebut. Makalah ini menerapkan studi kualitatif yang berorientasi pada pendekatan konsep teologis dan studi 
biblika. Data-data dikumpulkan melalui studi literatur.

Dalam uraian tentang esensi dari teologi proses, karya dari Whitehead akan menjadi sorotan penting. Di samping itu beberapa karya yang melakukan bahasan dan tinjauan terhadap pandangan Whitehead, akan juga menjadi sumber dalam uraian tersebut. Terkait dengan respons terhadap apa yang diajukan oleh teologi proses, makalah ini akan meninjau berdasarkan gagasan teologi salib dan laporan biblis berkaitan dengan penciptaan.

\section{HASIL DAN PEMBAHASAN}

\section{Konsepsi Allah-Proses}

Sebelum membahaskan lebih jauh mengenai Allah dalam teologi proses, ada hal-hal yang penting untuk diketahui mengenai kerangka pikir dari konsepsi Allah dalam teologi proses yang dilandaskan dari filsafat proses. Jadi, pembahasan mengenai filsafat proses akan menjadi kerangka dasar lahirnya teologi proses, untuk itu maka perlunya penjelasan yang baik mengenai filsafat proses. Filsafat ini dicirikan dengan sebuah usaha memperdamaikan intuisi-intuisi yang beragam dalam pengalaman manusia (seperti hal-hal yang agamawi, ilmiah dan keindahan) ke dalam skema holistik. Filsafat proses memodifikasi pernyataan Plato's Sophist, yang menegaskan hal-hal yang paling konkret adalah hal-hal yang nyata terlihat. Whitehead membahasakannya sebagai keber-Ada-an yang aktual (yang ada terlihat di saat itu). Dalam proses metafisika keber-Ada-an aktual itu bukan sepenuhnya penentu dari sebuah aktifitas dari terhadap yang lain, setiap keber-Ada-an memiliki kekuatan Penentu, sekecil apapun itu. Berdasarkan pandangan ini, memiliki kuasa dalam hubungan dengan yang lain adalah sebuah doktrin universal kreativitas. Hartshorne mengatakan "To be is to create" (Hartshorne,
1970, p. 270).

Interaksi antara partikel atom dan sub atom merupakan sebuah proses yang kemudian menghasilkan keber-Ada-an baru, jadi dalam proses tersebut adanya saling memberi antara satu dengan yang lain dan menghasilkan yang lain. Proses ini terus berlanjut dan tidak berhenti dan inilah yang dinamakan unsur kekal dalam filsafat proses. Momentum-momentum yang saling bertumbukan satu dengan yang lain atau berinteraksi menghasilkan entitas aktual yang terus-menerus sehingga membuat sebuah entitas kekal.

Dari kerangka filsafat proses itulah maka para teolog yang menerima filsafat ini, membuat sebuah spekulasi atau dugaandugaan mengenai konsepsi Allah. Mereka menerjemahkan konsep-konsep filsafat proses ini ke dalam konsep teologis, sehingga konsep teologi proses pun muncul dan berkembang dari waktu ke waktu dengan tanggapan dari berbagai teolog. Salah satu konsep yang sangat penting dalam teologi adalah konsepsi tentang Allah. Dalam bagian berikutnya untuk memaparkan konsepsi Allah dari teologi proses ini.

\section{Konsepsi Allah proses secara ontologis}

Pada bagian ini Whitehead sependapat dengan filsuf metafisika yaitu Aristoteles, Allah yang dimaksudkan oleh teologi proses adalah apa yang disebut sebagai Objek Kekal//deal. Inilah pengertian Objek Kekal Whitehead ditulis oleh Delwin Brown, Ralph James, Gene Reeves dalam Process Philosophy and Christian Thought:

For Whitehead as for Aristotle, process is the realizing of selected potentialities, or it is unexplainable. "Pure potentials for the specific determination of fact"-that is what eternal objects are (1971, p. 21).

Jadi inilah yang dimaksudkan oleh Whitehead mengenai "Allah". Dari manakah 
"Objek Kekal” berasal? Objek kekal ini adalah kemungkinan dari segala sesuatu yang konkret yang bisa terjadi. Keber-Ada-annya bagi Whitehead adalah dari sudah ada sebelumnya. Whitehead tidak percaya Ex Nihil Creatio. David Griffin dalam Physics and the Ultimate Significance of Time mengatakan:

Creation of our particular world was not initiated by a creation ex nihilo, in the sense of a total absence of finite forms of actuality, but was a creation out of chaos, out of a less ordered realm of finitude (1986, p. 139)

Dalam hal ini Griffin, memiliki pandangan yang sama dengan John B. Cobb. Cobb menyatakan bahwa Whitehead tidak menghubungkan pandangannya dengan Teori Big Bang, namun Whitehead meyakini bahwa semesta ini ada karena semesta-semesta yang telah ada sebelumnya dan tidak ada hubungannya dengan Allah atau dalam bahasa teknisnya adalah singularitas. ${ }^{1}$ Ini artinya bahwa tidak ada semesta itu bukan dari suatu kekosongan tetapi sebuah keberAda-an yang telah ada sebelumnya. Asumsi dasarnya adalah alam semesta ini berasal bukan dari sesuatu yang tidak terbatas tetapi dari sesuatu yang terbatas yang berasal dari zaman sebelumnya, belum beraturan dan memiliki potensi atau kemungkinan-kemungkinan dengan tujuan dan arah sendirinya. Jadi dari pandangan teologi proses tentang Allah adalah bahwa Allah merupakan objek-objek kekal yang memiliki potensi kemungkinan-kemungkinan yang menggerakan dan mengarahkan.

Para teolog proses menolak pandangan creatio ex nihilo, yang berarti penciptaan dari sesuatu yang sama sekali tidak ada. Mereka percaya penciptaan dari sesuatu yang kacau menjadi teratur dan terarah, karena mereka percaya ada zaman semesta yang telah ada dari semesta ini, sehingga bisa menjadi semesta ini. Lebih jauh menurut Rem B. Edward dalam How Process Theology Can Affirm Creation Ex Nihilo memberikan sebuah referensi pemikiran yang berkorelasi dengan pandangan teologi proses adalah Oscillationism beliau menyatakan:

Contemporary scientific Oscillationists usually affirm that our universe is but the most recent in a temporally infinite series of cosmic epochs, that it was created entirely, not by God, but by an influx of energy from an antecedently existing universe, that this prior universe originated from its own Big Bang (2000, p. 4).

Dalam pandangan Oscilasionism bahwa alam semesta ini berasal dari seri rangkaian masa atau zaman semesta yang disebut epoch, yang telah tercipta seluruhnya, tanpa ada penjelasan dari mana penciptaan itu berasal. Pengandaiannya adalah bahwa pada mulanya alam semesta itu sudah ada lengkap dengan bahan-bahan atau energi yang diperlukan lalu kemudian semestasemesta itu mengalami ledakan Big Bang mereka sendiri, sehingga menghasilkan ledakan terhadap semesta-semesta lain yang kemudian tercipta alam semesta lainnya.

Dapat dikatakan bahwa Allah proses itu mengacu pada natural theology. Cobb menjelaskan bahwa teologi proses didasarkan pada teologi alam, yang dalam hal ini filosofi Whitehead. Hal ini dikarenakan preposisi Cobb adalah teologi natural sebagai pengukur atau pengaku kebenaran dari teologi-teologi lainnya. Bukan hanya itu, ada sebuah kekhawatiran bahwa kosmologi modern tidak memiliki akar finalitas yang solid, sehingga dibutuhkanlah teologi natural ini (Cobb, 2000, pp. 3-4).

\section{Konsepsi Allah yang berproses atau mengalami proses}

Allah yang dipikirkan atau dirumuskan oleh para teolog proses adalah Allah yang 
memiliki natur yang selalu dalam perubahan atau proses sehingga dapat bersentuhan dan berelasi dengan dunia. Karena alam dan manusia mengalami perubahan maka Allah pun mengalami perubahan yang secara konstan. Whitehead menjelaskan bahwa Allah memiliki kutub "dipolar" (2 kutub yaitu kutub fisik dan mental), nama lain dari dua kutub tersebut adalah primordial nature dan consequent nature. Kutub fisik adalah kutub yang mengalami perubahan sedangkan kutub mental tidak mengalami perubahan namun keduanya tidak dapat terpisahkan satu dengan yang lain, bahkan saling berinteraksi (Whitehead, 1978, p. 348). Whitehead bicara tentang dua natur ini yang dikutip oleh Donald Viney, dalam The Stanford Encyclopedia of Philosophy, berkata demikian:

The primordial nature is God's envisagement of all possibilities ... It is called "primordial" because it represents what could be in a sense not tethered to actual course of events ... The consequent nature is God's prehensions of the actual processes of the world. Conversely, it is the world's influence on God. It is called "consequent" because it is consequent upon, or dependent upon, the decisions of non-divine actual entities (Whitehead calls them actual occasions). The consequent nature is the record of all achieved fact, a perfect memory of what has been -Whitehead speaks of the "objective immortality" of the world in God (2008, p. 10).

Jadi memang Allah dari teologi proses adalah Allah bukanlah Allah yang tidak berubah atau mengalami perubahan terus menerus tetapi Allah yang memiliki kedua natur tersebut di dalam diri-Nya.

Pertama, primordial: keteraturan, keharmonisan, dari sebuah objek kekal, Allah merupakan sebuah penjumlahan dari sebuah kemungkinan yang kekal (ide, dalam konsep Plato). Natur primordial adalah se- buah bayangan dan aturan-aturan dari objek abadi ke dalam sebuah ide yang tidak terbayangkan yang kompleks/rumit. Konsepsi kemungkinan yang ada di dalam pikiran Allah. Ini adalah abstraksi dari entitas aktual. Jadi natur ini adalah natur yang disebut juga what could be, artinya sesuatu yang bisa menjadi (kemungkinan), yang tidak terikat dengan peristiwa aktual.

Kedua, konsekuen: Allah mendapatkan dari dunia. Jika natur primordial adalah sebuah konsepsi kemungkinan-kemungkinan dalam pikiran Allah yang bersifat kekal, natur konsekuen adalah bagian dari diri Allah yang berinteraksi dengan mendapatkan sesuatu dari dunia secara aktual. Allah berkontribusi ke dalam dunia namun juga Allah itu diciptakan oleh dunia. Melalui interaksi dari entitas aktual atau peristiwaperistiwa aktual.

Inilah yang dimaksudkan natur Allah proses yang memiliki dua natur yaitu dipolar. Satu natur merupakan natur yang berinteraksi langsung dengan dunia dan dunia memberikan sumbangsih besar kepada Allah. Namun juga natur itu memberikan sumbangsih kepada dunia, walau lebih bersifat sumbangsih pasif dan tidak dapat memenentukan apapun. Karena interaksi dari dari dunia dan natur konsekuen merupakan hasil dari interaksi dari dua kekuatan penentu, yang menghasilkan kekuatan penentu lain dari keduanya. Sedangkan sisi natur primodial adalah natur yang ada secara terus-menerus sebagai potensi. Tidak secara aktif, namun sebuah kemungkinan-kemungkinan yang tidak tersentuh oleh natur konsekuen.

\section{Konsepsi Allah yang tidak berpribadi}

Berkenaan dengan Whitehead dan metafisika, buku Process and Reality menyatakan bahwa Allah yang dimaksudkan di dalam teologi proses adalah "yang banyak itu menjadi satu dan mengalami peningkatan 
oleh satu itu" (Whitehead, 1979, p. 21). Jadi Allah proses itu sendiri tidak dapat ditunjukkan oleh satu yang Ada. Dalam perkembangannya pandangan ini berkembang karena tidak adanya ikatan istilah yang dapat menggambarkan definisi Allah ini ke dalam bahasa singularitas, maka mulai dari situlah para teolog proses ini menggunakan istilah Allah dan mulai membahasakan filsafat ini ke dalam bahasa agama. Karena jika tidak demikian, konsepsi Allah dalam teologi proses akan sulit dijelaskan dalam kerangka yang mudah, karena tidak adanya singularitas dalam penamaannya.

Dalam bukunya Science and the Modern World, Whitehead pertama kalinya menyebut kata "Tuhan". Whitehead mengutip Aristoteles, ahli metafisika, dan telah mengenalkan Tuhan ke dalam sistem pemikirannya tanpa rujukan dari pengaruh agama apapun (1924, p. 249). Whitehead bermaksud membahas tema ini dalam pertimbangan-pertimbangan metafisika, dimana Tuhan disebut sebagai "abstraksi".

Dalam teologi proses, Allah direduksi hanya menjadi potensi, seperti kasih. Allah memiliki potensi untuk mengasihi, namun tidak mampu bertindak atas keinginannya sendiri untuk mengasihi. Allah dalam teologi proses mendasarkan keinginan dan pilihanpilihan-Nya berdasarkan sumbangsih-sumbangsih elemen-elemen yang ada di sekitarnya. Meskipun beberapa teolog proses berusaha mendaratkan teologi ini untuk menjawab persoalan manusia, khususnya persoalan kejahatan dalam dunia. Mereka meniadakan kehadiran Allah dalam kejahatan, bahwa memang Allah tidak memiliki kuasa untuk menaklukkannya.

\section{Konsepsi Allah yang tidak memiliki kekuatan sebagai penentu segala sesuatu secara mandiri}

Seperti yang telah dijelaskan di dalam bagian-bagian sebelumya, Whitehead menyebut pemikirannya tentang Tuhan sebagai sebuah sistem pemikiran yang mengacu pada ilmu filsafat, khususnya pada filsafat metafisika seperti Plato, Aristoteles dan Spinoza. Allah yang dirumuskan dan diyakini oleh Whitehead adalah berasal dari entitasentitas dalam sebuah kejadian yang saling berinteraksi satu dengan yang lain dan menghasilkan yang lain. Kesempatan-kesempatan aktual itu sendiri memiliki daya penentu namun tidak sepenuhnya bisa menentukan segalanya, namun entitas-entitas aktual itu harus saling mempengaruhi sehingga dapat menentukan kemungkin-kemungkinan berikutnya, walaupun di dalam istilah lain Whitehead menggunakan nama lain hasil dari benturan antara aktual entitas itu sebagai Nexus (Audi, 1995, pp. 851853). Dengan kata lain Nexus adalah hasil dari kekuatan-kekuatan penentu dari entitasentitas aktual yang saling berbenturan sehingga membentuk sesuatu yang lain. Namun, Nexus bukanlah hasil dari satu entitas aktual yang memiliki kekuatan penentu mutlak dan mandiri.

Jadi Allah dalam teologi proses bukan Allah yang memiliki kekuatan mutlak menentukan arah dan kejadian-kejadian menurut keinginan-Nya. Bahkan Allah proses adalah Allah yang tidak memiliki keinginan-keinginan. Kekuatan kuasa dari Allah proses adalah ikut merasakan dan menanggung rasa sakit akibat-akibat dari kejahatan dalam dunia. Bukan meniadakan kejahatan, namun berada menerima dampak-dampak dari kejahatan itu sendiri dan bukan mengendalikan atau menaklukkan kejahatan. Karena jika Allah proses adalah Allah yang terlibat dalam pengendalian dari kejahatan maka Allah itu bukan lagi Allah proses karena sudah memiliki kekuatan mandiri penentu kejahatan dan penakluk kejahatan. 


\section{Respons Terhadap Konsepsi Allah- proses}

Respons yang penulis sajikan adalah bukan hanya respons dari perspektif teologi Kristen saja, namun juga berdasarkan pada kerangka berpikir konsepsi Allah-proses tersebut, yang perlu dikritisi dan dipertimbangkan dengan lebih sistematis.

Pertama, Whitehead mengatakan bahwa dia memperkenalkan Tuhan untuk menyelesaikan masalah metafisika. Jika semua itu proses dan perubahan, lalu apa yang menyatukan segalanya, apa yang mencegah kemenangan entropi? Dan apa yang mengizinkan perkenalan terhadap hal-hal yang baru? Jawabannya adalah Tuhan, siapa yang menetapkan batasan-batasan, sebagai contoh antara masa lalu, masa kini dan masa depan. Jadi Whitehead sendiri memang mengakui perlu adanya konsepsi penentu untuk teologi proses ini sehingga dia memakai konsepsi Allah (plural). Dengan kata lain, Whitehead percaya bahwa adanya entitas aktual yang lebih dominan.

Kedua, selain pengakuan eksplisit itu teologi proses juga dibuat untuk langkah penyelesaian masalah kejahatan. Dalam masalah pendampingan jemaat dalam menghadapi persoalan kejahatan dan penderitaan di dunia, teologi proses memberikan pendekatan yang lebih empatif. Teologi proses memandang bahwa apa yang terjadi ketika kejahatan dan penderitaan hadir di dunia bukan karena berhubungan dengan Tuhan, namun Tuhan memberikan kebebasan kepada ciptaan-Nya sendiri untuk bersikap dan bertindak. Bukan karena Allah tidak Mahakuasa, tetapi karena kebaikan kasih-Nya. Kemahakuasaan Allah tidak terletak pada kemampuan untuk mencegah akibat dari penderitaan dan kejahatan itu, tetapi dalam kemampuan untuk menanggung segalanya tanpa dihancurkan olehnya, bahkan sebaliknya menjadikannya sarana penyelamatan. J. Sudarminta (2018, p. 13) menghubung- kan teologi proses ini dengan teologi salib, dimana keseriusan Inkarnasi atau penjelmaan Tuhan dalam Yesus Kristus berpartisipasi dalam pergumulan hidup manusia dan sebagai wujud kekuatan kasih yang menerima penderitaan. Inilah yang merupakan sisi teodesi dari teologi proses yang memang harus dipertimbangkan.

Ketiga, teologi proses menekankan bahwa Allah adalah Allah yang mengalami perubahan dan terus menerus mendapatkan sumbangsih dari dunia. Jika dikatakan bahwa Allah berubah terus-menerus maka Allah dapat dipengaruhi dan Allah tidak lagi menjadi Allah atas alam ini karena dia mampu diubah. Bukan dia lagi yang berkuasa tetapi suatu hal yang berkuasa itulah yang berkuasa atas Allah.

Keempat, walaupun ada sisi teodesi dalam teologi proses, namun memang teologi proses merupakan langkah meneropong yang supraalamiah di dalam kacamata alamiah. Para teolog proses masih mendasarkan argumentasinya di atas dasar kemungkinan-kemungkinan dari teori-teori alam yang mendukung konsepnya. Kemungkinan-kemungkinan dalam teologi proses telah dibatasi dalam kerangka alamiah. Pereduksian konsepsi Allah yang hanya dipandang sebagai potensi dan kemungkinan-kemungkinan, yang tidak memiliki kuasa mandiri menentukan segalanya. Kemungkinan-kemungkinan ini masih dalam kerangka ilmu alam, sehingga Allah dikurung oleh pandangan teologi alam. Konsepsi Allah ini tidak pernah dibebaskan atau diperluas dalam sudut pandang yang lain.

Kelima, konsepsi Allah yang memiliki dua natur merupakan sebuah konsep yang dapat dikatakan sulit dipahami dengan sepenuhnya, karena bagaimanakah mungkin natur kekal itu tidak bisa dipengaruhi oleh natur konsekuen? Sedangkan teologi proses juga membahas mengenai interaksi dunia dan Allah dalam hubungan saling 
mempengaruhi. Dalam konsepsi ini pun Whitehead masih menunjukkan adanya misteri yang tidak mampu dijelaskan. Hal ini juga berpengaruh terhadap konsepsi Allah yang merupakan objek-objek kekal yang tersimpan sebagai potensi, tentu tidak mampu menjelaskan hubungan antara potensi kepribadian dengan penampakkan kepribadian itu sendiri. Dengan kata lain, teologi proses tidak mampu menjelaskan mengenai sifatsifat Allah jika hal itu tidak dapat ditampakkan dalam sisi natur konsekuen. Natur kekal itu harus memiliki kestabilan kepribadian yang terwujud dalam natur konsekuen.

Keenam, kerangka filosofis telah membuat teologi proses menjadi kacamata satu-satunya dalam memandang teks biblis. Hal ini tidaklah tepat karena teks biblis memiliki keunikan dan kerangka pikir sendiri yang perlu dilihat dalam cara yang berbeda. Sehingga "kacamata" yang seharusnya dikenakan adalah penelitian literatur, sosial budaya dan konteks zaman.

Selain respons-respons di atas penulis juga menawarkan respons dari sisi biblis sebagai tambahan dalam makalah ini. Pertama, jelas mulai dari kitab pertama di Alkitab, bahwa Allah yang menjadi inisiator proses eksistensi alam ini. Allah dominan atas ciptaan-Nya. Bukan lagi sebuah perhitungan kemungkinan-kemungkinan fisik, namun eksistensi Allah menentukan eksistensi alam. Allah sebagai pelaku dan menjadi pemula sejarah. Allah telah ada tanpa proses dan Allah adalah penentu proses penciptaan. Allah yang memiliki tujuan-tujuan dan tindakan-tindakan yang berasal dari diri-Nya sendiri, tanpa pengaruh dari luar, Allah yang mutlak, mandiri dan self-existent (Rm. 1:1820).

Kedua, presupposisi iman Kristen adalah Allah pencipta alam semesta, dalam hal ini presuposisi tersebut didukung oleh analisa struktur literal yang terdapat dalam teks
Kejadian 1:1 sampai Kejadian 2:1-3 yang ditulis dalam bentuk chiastic atau chiasmus. ${ }^{2}$ Hal ini menunjukkan kesatuan arti bahwa ada dua subjek utama dalam Alkitab yaitu Allah dan manusia, atau ciptaan-Nya. ${ }^{3}$ Allah berperan aktif dalam penciptaan dari tidak ada apa-apa sampai hari keenam saat Allah menciptakan manusia, dan Allah memberkati hari ketujuh. Argumentasi ini merupakan sebuah penegasan teologi Perjanjian Lama bahwa Allah adalah Pencipta Tunggal yang menciptakan alam semesta beserta segala isinya dari sesuatu yang tidak ada menjadi ada. Analisa biblis ini pun harus menjadi sebuah pertimbangan dalam memahami konsepsi Allah dari sudut pandang teks biblis.

Ketiga, pemahaman teologis mengenai natur Allah konsisten dengan penuturan dan pemaparan Alkitab tentang setiap tindakan Allah dalam sejarah dari Perjanjian Lama sampai Perjanjian Baru. Contoh yang sederhana, Allah adalah kasih, maka Allah menciptakan makhluk hidup setelah Dia menciptakan tempat hidup bagi makhluk hidup tersebut. Dengan Allah memenuhi kebutuhan penopang hidup para makhluk ini, Allah bertindak konsisten dengan sifat-Nya, yaitu kasih. Dia konsisten dengan sifat-Nya yang dinyatakan dalam tindakan-Nya. Tindakan Allah bertindak terhadap dosa manusia, bahwa setiap dosa memiliki konsekuensi. Namun, Allah tidak berhenti di sana, Allah konsisten dengan kasih-Nya, sehingga Dia memberikan pengharapan dan keselamatan bahkan sebenarnya anugerah penerimaan bagi manusia, melalui tindakan Allah mengenakan baju pada manusia untuk menutupi rasa malu mereka. Bahkan dalam peristiwa lain, Kain yang adalah seorang pembunuh adiknya, Habel, yang harus mengalami konsekuensi dan menjadi pelarian, Kain pun mendapat perlindungan Allah. Jadi Allah dalam teologi Kristen dan fakta biblika yang ada, digambarkan sebagai Allah yang memiliki kepribadian yang aktif, bukan hanya 
sekadar potensi, namun Dia benar-benar Allah yang menyatakan tindakan-Nya kongruen dengan sifat-Nya.

\section{KESIMPULAN}

Teologi proses merupakan hasil dari pola pikir filsafat proses yang kemudian dikenakan pada dunia teologi. Teologi proses memandang Allah sebagai entitas aktual, mengalami proses, sifat-sifat Allah merupakan potensi dan natur luar mengalami perubahan terus menerus, tidak memiliki kekuatan penentu sendiri namun bergantung pada sumbangsih dunia. Ada sisi teodesi yang juga merupakan sumbangsih yang baik dari teologi proses untuk perkembangan pemikiran teologi untuk pendam-

\section{DAFTAR RUJUKAN}

Audi, R. (1995). The Cambridge Dictionary of Philosophy. London: The Press Syndicate of the University of Cambridge.

Breck, J. (1991). The Shape of Biblical Language: Chiasmus in the Scriptures and Beyond. New York: St. Vladimir's Seminary Press.

Cobb, J. B. (2000). A Christian Natural Theology Based on Thought of Alfred North Whitehead. Philadelphia: Westminster Press.

Edwards, R. B. (2000). Process Studies. Claremont: Center for Process Studies.

Griffin, D. R. (1986). Physics and the Ultimate Significance of Time. New York: State University Of New York

\section{ENDNOTE}

1. John B. Cobb, Jr. replies that "Whitehead knew nothing of the 'Big Bang' and thought instead of cosmic epochs evolving out of earlier cosmic epochs with no singularities involved. Process theology followed pingan jemaat. Walaupun, teologi proses adalah teologi alam, namun teologi wahyu pun perlu mempertimbangkannya dimana teologi alam lebih ramah dengan lingkungannya. Untuk hal ini, maka teologi proses hanya bisa dipandang sebagai teologi natural yang tidak mampu memberikan pandangan menyeluruh mengenai Allah dalam konteks teologi biblis Kristen, yang memiliki presuposisi yang berbeda. Maka perlu ada respons yang menunjukkan mengenai konsep Allah teologi biblis, khususnya analisa struktur literasi dalam kitab Kejadian dan beberapa gambaran bagaimana sifat Allah sesuai dengan tindakannya, dalam arti tidak mengalami perubahan atau proses.

press.

Hartshorne, C. (1970). Creative Synthesis and Philosophic Method. Lanham: UP of America.

Sudarminta, J. (2018). Alfred Whitehead: Tuhan Sebagai "The Poet of the world" Sebuah Gambaran Metaforis Tentang Dialektika Hubungan Tuhan dan dunia (Class handout).

Viney, D. (2008). The Stanford Encyclopedia of Philosophy. California: Stanford University.

Wenham, J. G. (1987). Genesis 1-15. World Biblical Commentary. Dallas: Word Book.

Whitehead, N. (1978). Process and Reality: An Essay in Cosmology. New York: Free Press.

2. Chiasmus dalam hal ini mendapat peran penting dalam studi biblika, hal ini dikarenakan pada zaman Alkitab tidak menggunakan paragraf, tanda baca, huruf besar dan spasi. Chiasmus digunakan untuk 
mengarahkan pembaca pada tema pusat atau makna dari teks tersebut (Breck, 1991, pp. 60-99).

3. 1:1-2:3 form the first section of Genesis; the second starts with 2:4. 2:1-3 echoes 1:1 by introducing the same phrases but in reverse order: "he created," "God," "heavens and earth" reappear as "heavens and earth" (2:1) "God" (2:2), "created" (2:3). This chiastic pattern brings the section to a neat close which is reinforced by the inclusion "God created" linking 1:1 and 2:3 (Wenham, 1987). 